\title{
Optimizing Protein Intake and Nitrogen Balance (OPINiB) in Adult Critically III Patients: A Study Protocol for a Randomized Controlled Trial
}

Matteo Danielis ${ }^{1}$, RN; Giulia Lorenzoni ${ }^{2}$, MA; Laura Cavaliere ${ }^{2}$, MA; Mariangela Ruffolo ${ }^{2}$, MA; Luca Peressoni ${ }^{1}$, RN; Amato De Monte ${ }^{1}, \mathrm{MD}$; Rodolfo Muzzi ${ }^{1}$, MD; Fabio Beltrame ${ }^{1}, \mathrm{MD}$; Dario Gregori ${ }^{2}$, PhD

${ }^{1}$ Department of Anaesthesia and Intensive Care-Azienda Sanitaria Universitaria Integrata di Udine, Udine, Italy
${ }^{2}$ Unit of Biostatistics, Epidemiology, and Public Health, Department of Cardiac, Thoracic, and Vascular Sciences, University of Padova, Padova, Italy

Corresponding Author:

Dario Gregori, $\mathrm{PhD}$

Unit of Biostatistics, Epidemiology, and Public Health

Department of Cardiac, Thoracic, and Vascular Sciences

University of Padova

Via Leonardo Loredan 18, 35121

Padova,

Italy

Phone: 390498275384

Fax: 3902700445089

Email: dario.gregori@unipd.it

\section{Abstract}

Background: Adequate nutrition of critically ill patients plays a key role in the modulation of metabolic response to stress.

Objective: This paper presents the development of a protocol for a randomized controlled trial (RCT) aimed at comparing clinical outcomes of patients in the intensive care unit (ICU) administered with standard and protein-fortified diet. Together with the RCT study protocol, the results of the observational analysis conducted to assess the feasibility of the RCT are presented.

Methods: An RCT on adult patients admitted to ICU and undergoing mechanical ventilation in the absence of renal or hepatic failure will be conducted. Patients enrolled will be randomized with an allocation rate of 1:1 at standard diet versus protein-fortified diet. The estimated sample size is 19 per arm, for a total of 38 patients to be randomized.

Results: Enrollment began in January 2017. In the feasibility study, 14 patients were enrolled. Protein administration increased significantly $(P<.001)$ over time but was significantly lower compared to that recommended $(P<.001)$. Blood urea nitrogen significantly increased $(P<.03)$ over the period of observation. Such increased catabolism resulted in negative cumulative nitrogen balance (NB) in all patients, and some patients presented with a more negative NB compared to the others.

Conclusions: Results of the feasibility study clearly confirmed that protein provision in ICU patients is below that recommended and that this results in impaired NB. The emerging of an interindividual variability in NB will be further analyzed in the RCT.

Trial Registration: ClinicalTrials.gov NCT02990065; https://clinicaltrials.gov/ct2/show/NCT02990065 (Archived by WebCite at http://www.webcitation.org/6prsqZdRM).

(JMIR Res Protoc 2017;6(5):e78) doi: 10.2196/resprot.7100

\section{KEYWORDS}

nitrogen balance; protein requirements; catabolism; mechanical ventilation; intensive care unit

\section{Introduction}

In recent years, several studies have focused on the molecular and biological effects of nutrients in maintaining homeostasis in patients admitted in intensive care unit (ICU), and ad hoc recommendations have been developed for the assessment and provision of nutritional support in adult critically ill patients $[1,2]$. In such patients, specific metabolic mechanisms are activated to face stresses related to critical conditions (eg, trauma and sepsis). These metabolic responses consist of changes in substrate utilization and substance synthesis rates, as well as catabolism and hypermetabolism, resulting in increased energy 
expenditure, hyperglycemia, loss of body mass, and eventually psychological and behavioral problems [3]. Given such framework, monitoring the metabolic response is crucial in the management of ICU patients. However, this represents a major clinical challenge since it is generally assessed indirectly using nonspecific clinical and biochemical markers such as secondary infections, muscle atrophy and weakness, respiratory insufficiency, delayed wound healing, and incidence of secondary complications indicating prolonged catabolism [4]. Adequate nutrition plays a key role in the modulation of metabolic response to stress, contributing to the prevention of oxidative cellular injury and positively modulating immune responses.

All patients admitted in ICU require a full nutritional assessment for determining both energy and protein requirements to prevent malnutrition. According to international guidelines [2], the best approach is to reach the energy goal by indirect calorimetry (IC) when available. In the absence of IC, a predictive formula or simple weight-based equation (25-30 kcal/kg/day) may be used to determine energy requirements [2]. Although no consensus has been reached about the most accurate formula to be used in ICU, the Harris-Benedict equation (HBE) is the most often employed to estimate the resting energy expenditure (REE) in ICU patients [5]. However, these equations suffer from several limitations, including poor accuracy. Their poor accuracy is related to the fact that the variables affecting energy expenditure in critically ill patients (eg, weight, medications, treatments, and body temperature) are sensitive to changes over time. For mechanically ventilated patients in ICU, the main factors influencing REE have been found to be weight, height, body temperature, and minute ventilation [6].

In the critical setting, protein is the macronutrient most often lacking in such patients, and its supplementation is likely to result in beneficial effects [7]. Disorders of protein metabolism are documented as physiologic responses to stressful events and are reflected by important nitrogen loss and muscle wasting, which are proportional to the severity of illness [8]. Current evidence supports the early administration of protein supplementation because a stressful event alters homeostatic balance, resulting in an increased protein catabolism [9]. Administering exogenous protein or amino acid is crucial to reduce the breakdown of endogenous proteins by providing an alternative source of amino acids for gluconeogenesis and protein synthesis. Protein-energy deficit is associated with an increased rate of infection, poor wound healing, reduced respiratory muscle mass, and delayed weaning from mechanical ventilation, resulting in increased length of stay in ICU and increased care costs [10]. A high protein intake, estimated using a weight-based equation (1.2-2 $\mathrm{g} / \mathrm{kg} / \mathrm{day})$, is recommended during the ICU stay regardless of the simultaneous caloric intake $[9,11]$.

This paper presents the development of a protocol for a randomized controlled trial (RCT) aimed at assessing changes of nitrogen balance (NB) in ICU patients administered with standard parenteral/enteral diet and protein-fortified parenteral/enteral diet. Together with the study protocol, results of the pilot study conducted to assess the feasibility of such a trial are also presented.

\section{Methods}

\section{Randomized Controlled Trial}

\section{Study Design and Randomization}

This study has been designed as a parallel arm RCT enrolling patients admitted at the Department of Anaesthesia and Intensive Care - Azienda Sanitaria Universitaria Integrata di Udine (Italy). Medical and surgical adult patients admitted to ICU undergoing mechanical ventilation at the time of admission or in the first 12 hours will be enrolled. See Textbox 1 for selection criteria.

Textbox 1. Selection criteria.

Inclusion criteria:

- $\quad$ Aged 18 years and older

- Receiving parenteral nutrition or enteral nutrition

- Having an indwelling catheter

- Undergoing mechanical ventilation

Exclusion criteria:

- Current or 6-month past history of gastrointestinal bleeding

- $\quad$ body mass index $<18.5 \mathrm{~kg} / \mathrm{m}^{2}$ or $\geq 30 \mathrm{~kg} / \mathrm{m}^{2}$

- Terminal illness

- Pregnancy

- Acute renal failure defined using Kidney Disease Improving Global Outcomes (KDIGO) Clinical Practice Guidelines [12]: patients with a KDIGO stage 2 (serum creatinine 2-2.9 times baseline or urine output $<0.5 \mathrm{~mL} / \mathrm{kg} / \mathrm{h}$ for 12 hours) and 3 (increase in serum creatinine $\geq 4 \mathrm{mg} / \mathrm{dL}$, anuria for more than 12 hours, or starting of renal replacement therapy)

- Hepatic failure 
Patients enrolled will be randomized to standard nutritional care (standard diet) to meet daily patient caloric requirement (control group) or appropriate amount of protein feeding (protein-fortified diet) to meet daily patient protein requirement (intervention group). Random allocation will be performed using a computer-generated algorithm (with an allocation rate of 1:1). Subjects enrolled will remain in the study until they are no longer mechanically ventilated. Participants will be blinded to treatment allocation. The flowchart of the study protocol is shown in Figure 1.

Figure 1. Flowchart of the study protocol.

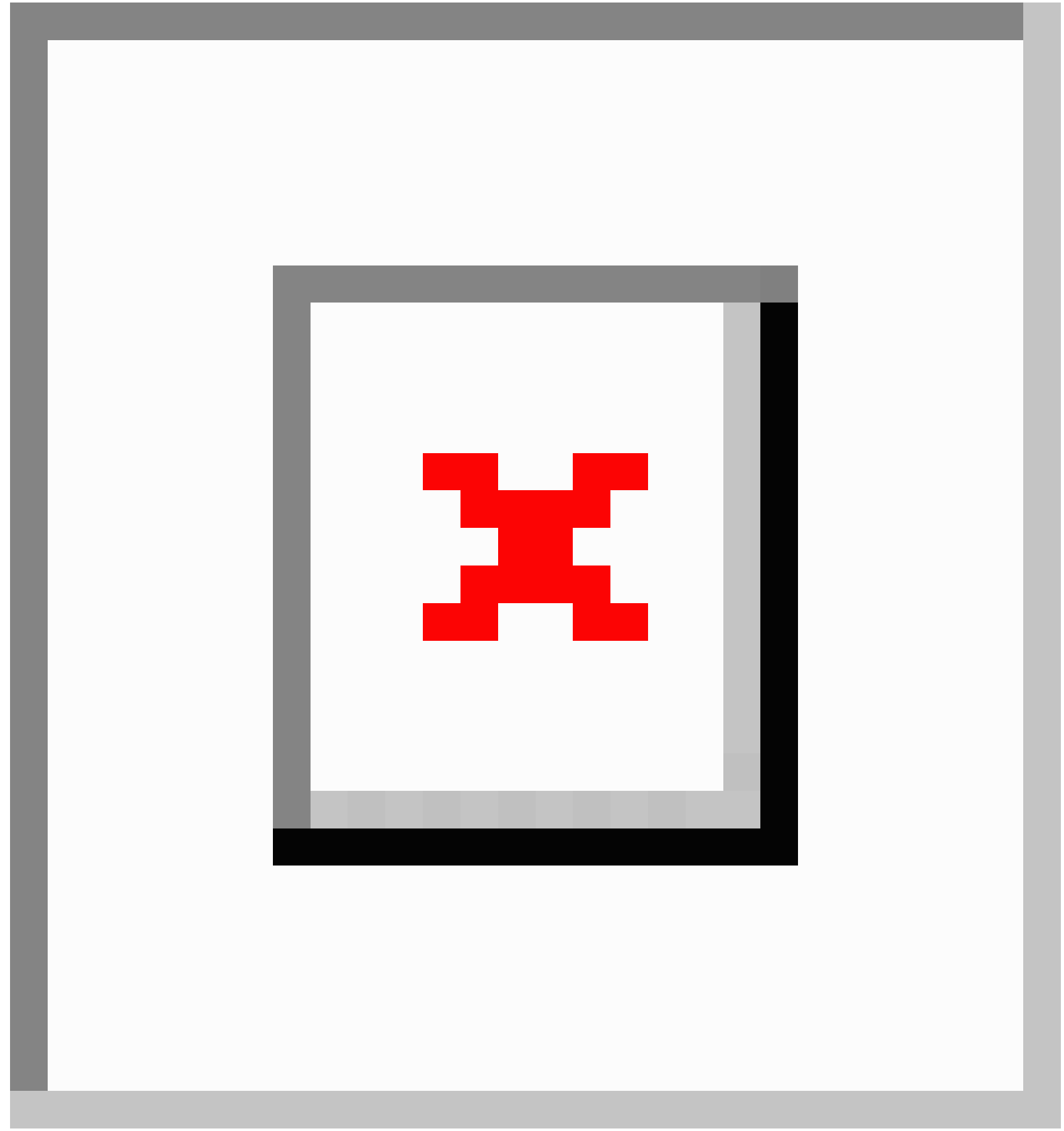

\section{Treatment Arms}

The standard diet consists of an energy goal based on weight formula (20-25 kcal/kg/day). According to the ICU nutritional protocol, enteral nutrition (EN) will be started at an initial rate of $10 \mathrm{~mL} / \mathrm{h}$ and increased by $20 \mathrm{~mL} / \mathrm{h}$ every 12 hours in the absence of significant gastric residuals $(<250 \mathrm{~mL})$, with the aim of reaching the energy goal within 72 hours of admission. The $\mathrm{EN}$ formulae used are standard (1-1.5 $\mathrm{kcal} / \mathrm{mL}, 40 \mathrm{~g} / \mathrm{L}$ protein).
If EN is not tolerated or not indicated, supplemental parenteral nutrition (PN) will be used to make up the energy shortfall. The $\mathrm{PN}$ formula used is standard (1000 kcal/L, $37 \mathrm{~g} / \mathrm{L}$ protein).

The protein-fortified diet consists of an energy goal based on REE and a protein target based on the most recent literature recommendations (1.2-2 g/kg/day) [2]. Daily caloric requirement and subsequent protein content for patients enrolled in the intervention group will be calculated using formulae reported 
in Multimedia Appendix 1 [10,13,14]. For each patient, it will be calculated based on the REE and the daily protein requirement $(1.2-2 \mathrm{~g} / \mathrm{kg} / \mathrm{day}$ of body weight registered at time of admission) and the corresponding caloric intake ( $1 \mathrm{~g}=4 \mathrm{kcal})$. Daily total caloric intake will be represented by $50 \%$ protein ( 1 $\mathrm{g}=4 \mathrm{kcal}$ ) and another $50 \%$ nonprotein (ie, fat and carbohydrates).

For the intervention group, EN will be started at an initial rate of $10 \mathrm{~mL} / \mathrm{h}$ and increased by $20 \mathrm{~mL} / \mathrm{h}$ every 8 hours in the absence of significant gastric residuals $(<250 \mathrm{~mL})$ with the aim of reaching the energy goal within 48 hours of admission. The EN formulae used are high in protein $(1-1.5 \mathrm{kcal} / \mathrm{mL}, 74 \mathrm{~g} / \mathrm{L}$ protein). If EN is not tolerated or not indicated, supplemental $\mathrm{PN}$ is used to make up the energy shortfall. The PN formula used will be arranged by the hospital pharmacy to meet the energy targets set for the intervention group.

For patients enrolled in the control group and the intervention group, gastric residuals will be checked 4 times per day and electrolytes will be closely monitored and replaced. Adequacy of nutritional support will be determined daily by measuring NB.

\section{Data Collection}

Age (years), gender, weight $(\mathrm{kg})$, height $(\mathrm{cm})$, body mass index (BMI) $\left(\mathrm{kg} / \mathrm{m}^{2}\right)$, main diagnosis, clinical history, and illness severity assessed using the Acute Physiology and Chronic Health Evaluation (APACHE) II score [15] will be collected at time of admission in ICU (baseline assessment). The Simplified Acute Physiology Score (SAPS) II for mortality prediction in ICU [16] will also be calculated.

The following parameters will be recorded at midnight of each day: caloric intake, protein intake, measurement of 24-hour urine urea nitrogen (UUN) excretion, blood creatinine, NB, blood urea nitrogen (BUN) level, average blood glucose, amount of propofol administered (mL/day), amount of dextrose administered (mL/day).

A standard formula will be used for NB calculation [17,18]: total protein intake $(\mathrm{g}) / 6.25-(\mathrm{UUN}+4 \mathrm{~g})$, where $6.25=6.25$ $\mathrm{g}$ of protein per gram of nitrogen, $\mathrm{UUN}=$ grams of nitrogen excreted in the urine over 24-hour period of time, and $4=4 \mathrm{~g}$ of nitrogen lost each day as insensible losses via the skin and gastrointestinal tract. Additionally, for each patient, the duration of mechanical ventilation and any infection or skin alteration discovered during the study period will be reported.

\section{Sample Size}

Considering NB as primary outcome, a sample size estimation has been performed considering a $t$ test difference in means between the 2 groups (standard and protein-fortified diet). For a specified alpha of .025 and a power of 0.90 , which aimed at detecting a difference of at least $-6 \mathrm{~g}$ of NB between the 2 groups (assuming an equal standard deviation in the 2 groups of $5 \mathrm{~g}$ ), the estimated sample size is 19 per arm for a total of 38 patients to be randomized. The sample size has been estimated using the sample size package in R software (The R Foundation) [19].
Data will be entered and managed using REDCap (Research Electronic Data Capture), a Web-based application for managing databases hosted at the Department of Cardiac Thoracic and Vascular Sciences, University of Padova (Italy).

\section{Statistical Analysis Plan}

The primary endpoint will be analyzed for the intention-to-treat (ITT) population. After having reached the sample size foreseen, a $t$ test with an alpha level equal to .025 will be performed to assess the statistical differences in NB between protein-fortified diet and standard diet arms. As secondary endpoint, the hospital mortality rate will be considered. On the ITT population, the secondary endpoint will be evaluated by testing the difference between the 2 groups in a logistic model framework (alpha=.025).

The study was approved by the regional ethics committee of Friuli Venezia Giulia, Italy (CEUR-2016-Sper-066-ASUIUD). Each patient or legally authorized representative must provide written informed consent for the study procedures.

\section{Feasibility Study}

\section{Study Design}

An observational analysis was conducted to assess the feasibility of the trial. This observational study enrolled patients admitted to the ICU of the Department of Anaesthesia and Intensive Care - Azienda Sanitaria Universitaria Integrata di Udine (Italy). The study was undertaken in a group of mixed medical, surgical, and trauma patients undergoing mechanical ventilation. Exclusion criteria were age (less than 18 years), chronic renal (identified using KDIGO recommendations) or hepatic failure, current or 6-month past history of gastrointestinal bleeding, body mass index $<18.5 \mathrm{~kg} / \mathrm{m}^{2}$ or $\geq 30 \mathrm{~kg} / \mathrm{m}^{2}$, terminal illness, and pregnancy. This study aimed at investigating the level of energy intake (kcal and protein) and nitrogen excretion in an ICU population receiving standard diet.

\section{Treatment}

Our nutritional approach was led by current guidelines that recommend providing $25-30 \mathrm{kcal} / \mathrm{kg} /$ day. Both EN and PN were used to achieve energy goals. EN formula was the Nutrison standard (1000 kcal and $40 \mathrm{~g}$ of protein per $1000 \mathrm{~mL})$; an all-in-one solution containing $1000 \mathrm{kcal}$ and $47 \mathrm{~g}$ of protein per $1000 \mathrm{~mL}$ was used for PN.

\section{Data Collection}

Using REDCap, the following patient information were collected: admission diagnosis, comorbidities, age, sex, BMI, APACHE II score, SAPS II score (at baseline), type and amount of nutrition received (both caloric and protein intake), amount of propofol and dextrose (mL/day) administered, and blood chemistry (urea nitrogen level, creatinine, glucose) (at midnight of each day). A daily 24-hour urine collection was conducted in all patients and NB was calculated. For each patient, any infection or skin alteration occurring during the study period was reported. Daily data were collected until the end of mechanical ventilation or until renal/hepatic acute failure, death, or discharge from the ICU. 


\section{Data Analysis}

Continuous variables were reported as median (I quartile and III quartile), and discrete parameters were reported as absolute value (percentage). The distribution of the quantitative variables was summarized using simple barplots for trend. To assess if the series has an increasing or decreasing trend, a nonparametric Spearman test was performed between the observations and time. To calculate trends, means of patient measures of interest were considered. A $t$ test was carried out to test the significance of mean difference from the amount of protein actually administered and that recommended by international guidelines. All analyses were performed using $\mathrm{R}$ software (The $\mathrm{R}$ Foundation) [19].

\section{Results}

\section{Randomized Controlled Trial}

Enrollment in the study began in January 2017. Data collection is expected to be conducted until April 2017. Data analysis will start once the data collection is completed and the database is locked.

\section{Feasibility Study}

Sample characteristics are summarized in Table 1. A total of 14 patients were enrolled, with a median age of 48 years. Median weight was $83 \mathrm{~kg}$, and median BMI was $25.5 \mathrm{~kg} / \mathrm{m}^{2}$. For about a half of the patients $(6 / 14,43 \%)$ the main diagnosis reported at time of admission was trauma (especially multiple trauma). Of the 14 patients evaluated, $8(57 \%)$ completed the observation until the end of mechanical ventilation.
Figure 2 shows the contribution of EN, PN, extra proteins (represented by albumin), and propofol and dextrose infusions to the mean energy (kcal) intake over the feasibility study period. During the first 3 days of observation, propofol contributed to about half of the daily caloric intake. Additionally, calories introduced by PN increased over the days, while calories provided by EN remained stable. Overall, caloric intake increased over time. Along with caloric intake, protein administration also increased significantly $(P<.001)$ over the period of observation (Figure 3).

Despite the increased provision of protein during hospitalization, the BUN significantly increased $(P=.03)$ over the period of observation (Figure 4), thus indicating an increased catabolism in patients enrolled (since urea represents the waste product from protein metabolism). Increased catabolism resulted in negative NB, as shown in Figure 5. All patients had a negative cumulative NB in the first 72 hours of observation, and some patients presented with a markedly more negative NB compared to the others.

Finally, Figure 6 reports the comparison between patients' actual protein intake and that recommended by international guidelines (considering a value of $1.8 \mathrm{~g} / \mathrm{kg} /$ day in the range between 1.2 and $2 \mathrm{~g} / \mathrm{kg} / \mathrm{day}$ ). Clearly, the amount of protein actually administered is significantly lower compared to that recommended $(P<.0001)$ (for patient $7, \mathrm{PN} / \mathrm{EN}$ was not administered in the first 24 hours due to medical procedures, resulting in fasting). The median difference between actual and recommend protein intake was found to be $-360 \mathrm{~g} / \mathrm{kg}$ (range -638 to 52 ).

Figure 2. Composition of the calories administered.

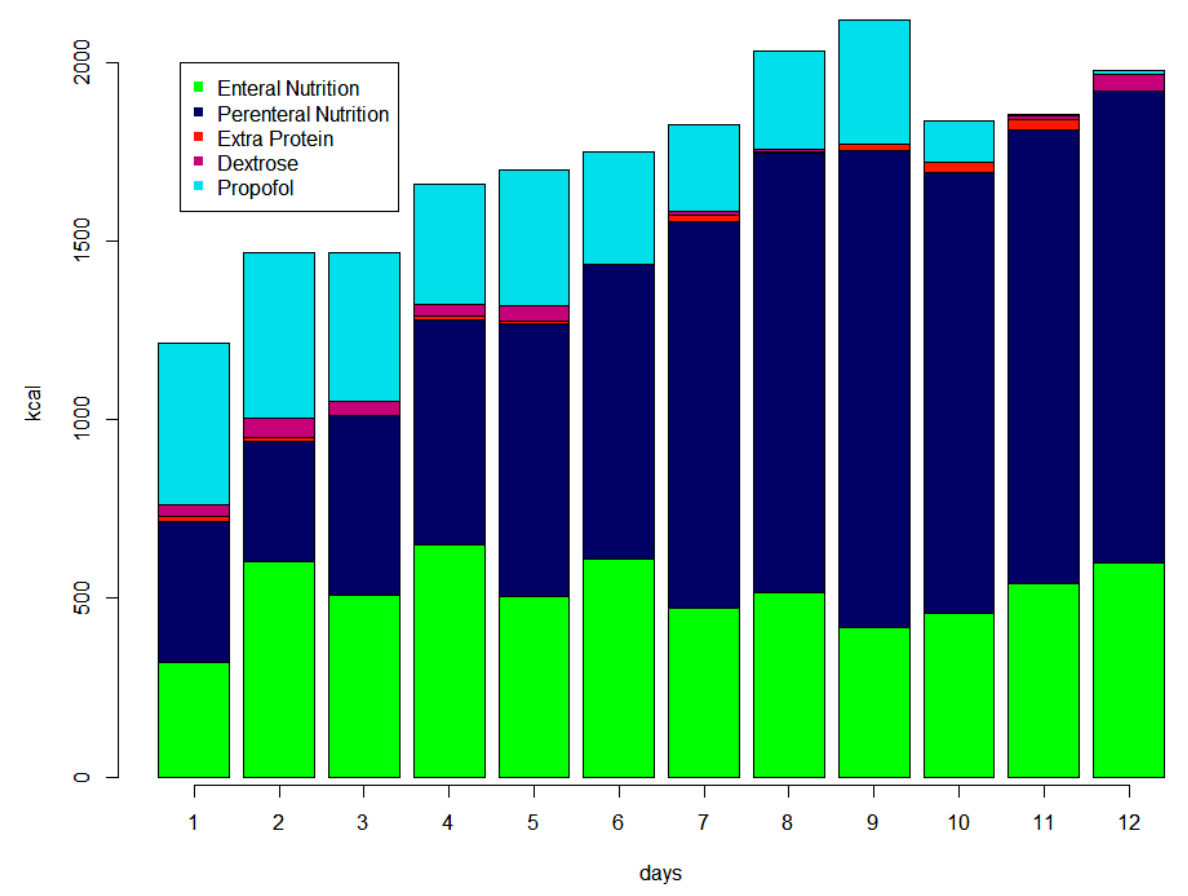


Table 1. Characteristics of the patients enrolled in the feasibility study.

\begin{tabular}{|c|c|c|c|}
\hline Characteristics & & & Number \\
\hline $\begin{array}{l}\text { Age (years), median (I and III } \\
\text { quartile) }\end{array}$ & & & $48(43-55)$ \\
\hline \multicolumn{4}{|l|}{ Sex, $n(\%)$} \\
\hline & Male & & $8(57)$ \\
\hline & Female & & $6(46)$ \\
\hline $\begin{array}{l}\text { Weight }(\mathrm{kg}) \text {, median (I and III } \\
\text { quartile) }\end{array}$ & & & $83(66-94)$ \\
\hline $\begin{array}{l}\mathrm{BMI}^{\mathrm{a}}\left(\mathrm{kg} / \mathrm{m}^{2}\right) \text {, median (I and III } \\
\text { quartile) }\end{array}$ & & & $25.5(24.2-27)$ \\
\hline $\begin{array}{l}\text { APACHE }{ }^{b} \text { II score, median (I and } \\
\text { III quartile) }\end{array}$ & & & $10.5(9-16)$ \\
\hline $\begin{array}{l}\text { SAPS }^{\mathrm{C}} \text { II score, median (I and III } \\
\text { quartile) }\end{array}$ & & & $29(24-36)$ \\
\hline $\begin{array}{l}\text { Observation period (days), medi- } \\
\text { an (I and III quartile) }\end{array}$ & & & $8(6-12)$ \\
\hline \multicolumn{4}{|l|}{ Admission diagnosis, n (\%) } \\
\hline & Organ failure & & $4(29)$ \\
\hline & & Respiratory failure & $3(75)$ \\
\hline & & Sepsis and infection & $1(25)$ \\
\hline & Trauma & & $6(43)$ \\
\hline & & Multiple trauma & $5(83)$ \\
\hline & & Spinal trauma & $1(17)$ \\
\hline & $\begin{array}{l}\text { Cerebrovascular dis- } \\
\text { ease }\end{array}$ & & $4(29)$ \\
\hline & & Cerebral hemorrhage & $2(50)$ \\
\hline & & Coma & $2(50)$ \\
\hline \multicolumn{4}{|l|}{ Comorbidities, n (\%) } \\
\hline & $\begin{array}{l}\text { Cerebrovascular acci- } \\
\text { dent }\end{array}$ & & $3(21)$ \\
\hline & $\begin{array}{l}\text { Chronic obstructive } \\
\text { pulmonary disease }\end{array}$ & & $1(7)$ \\
\hline & Diabetes & & $2(14)$ \\
\hline & Hypertension & & $3(21)$ \\
\hline & Smoking & & $2(14)$ \\
\hline & Anxiety/depression & & $2(14)$ \\
\hline & Neoplasia & & $1(7)$ \\
\hline \multicolumn{4}{|l|}{ Exit study, n (\%) } \\
\hline & $\begin{array}{l}\text { Transfer to another } \\
\text { hospital }\end{array}$ & & $2(14)$ \\
\hline & $\begin{array}{l}\text { Term of mechani- } \\
\mathrm{cal} / \text { spontaneous } \\
\text { breathing }\end{array}$ & & $8(57)$ \\
\hline & $\begin{array}{l}\text { Acute renal or hepatic } \\
\text { failure }\end{array}$ & & $3(21)$ \\
\hline & Death & & $1(7)$ \\
\hline
\end{tabular}

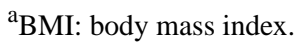


bAPACHE: Acute Physiology and Chronic Health Evaluation.

${ }^{\mathrm{c}}$ SAPS: Simplified Acute Physiology Score.

Figure 3. Protein intake trend.

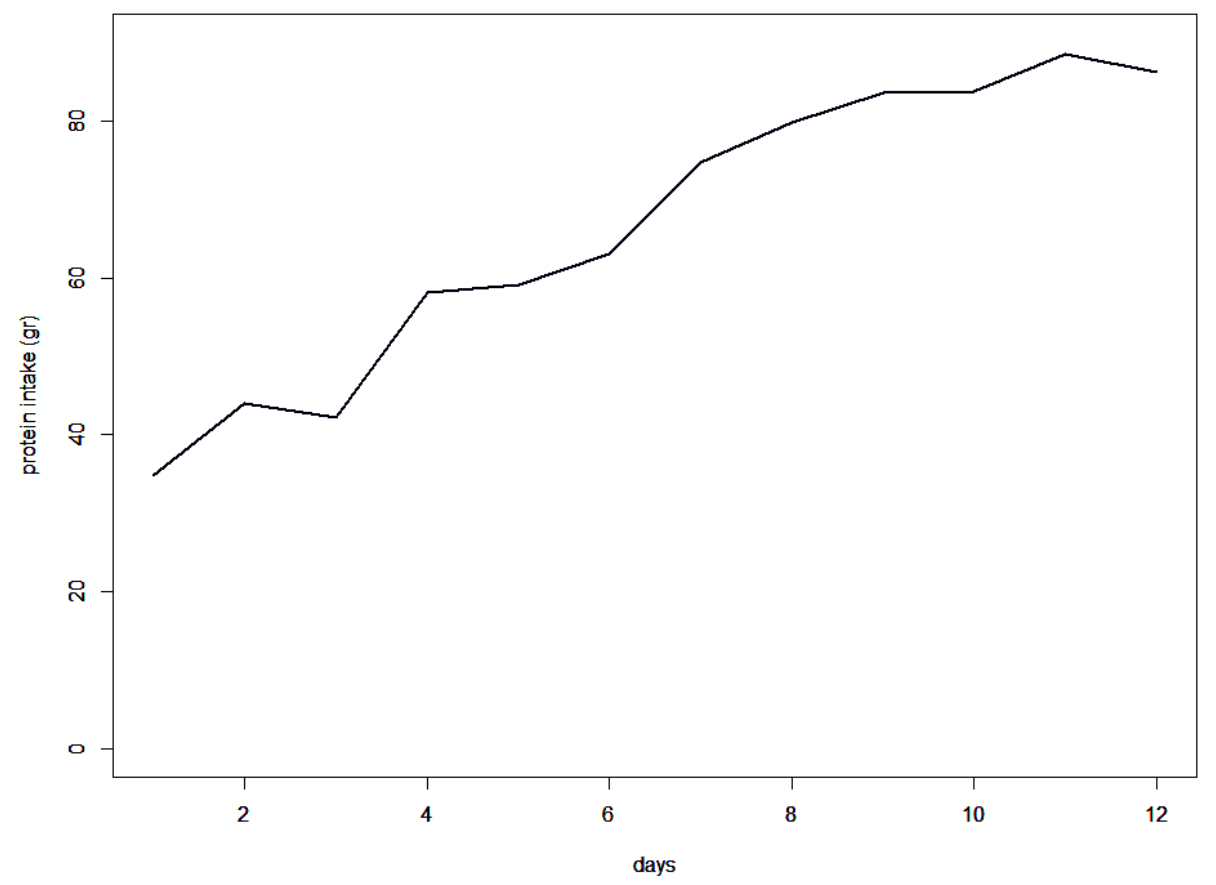

Figure 4. Blood urea nitrogen trend.

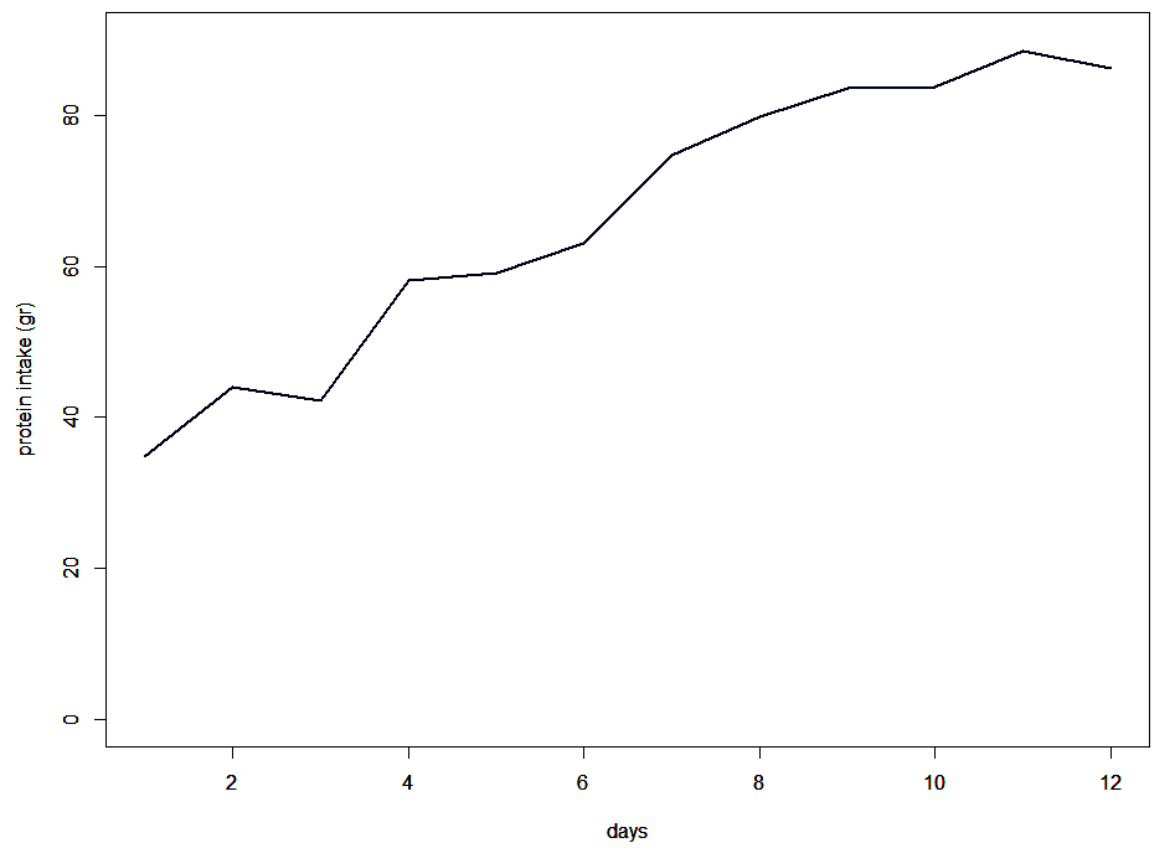


Figure 5. Cumulative nitrogen balance during the first 72 hours.

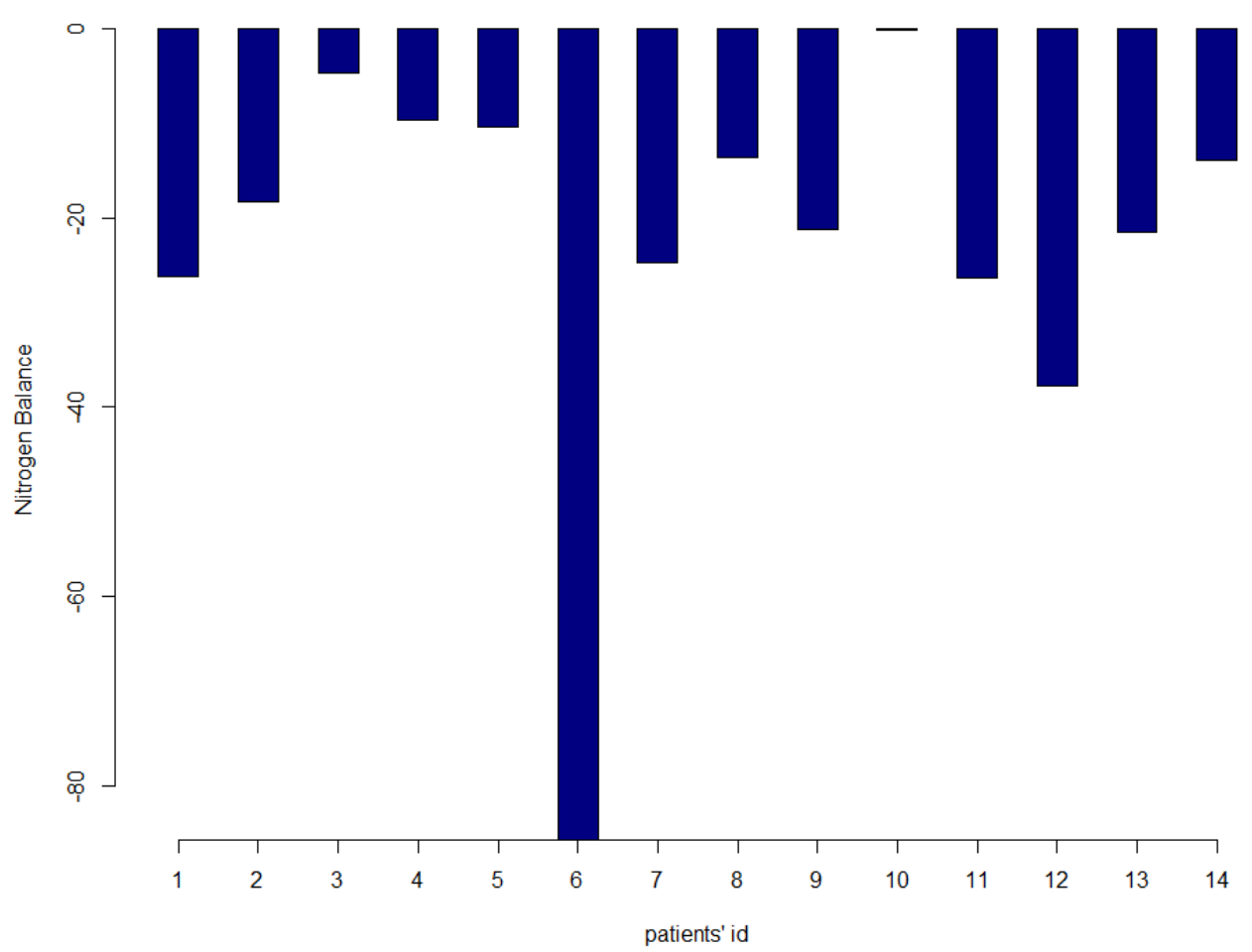

Figure 6. Protein intake administered versus ideal protein target in the first 24 hours.

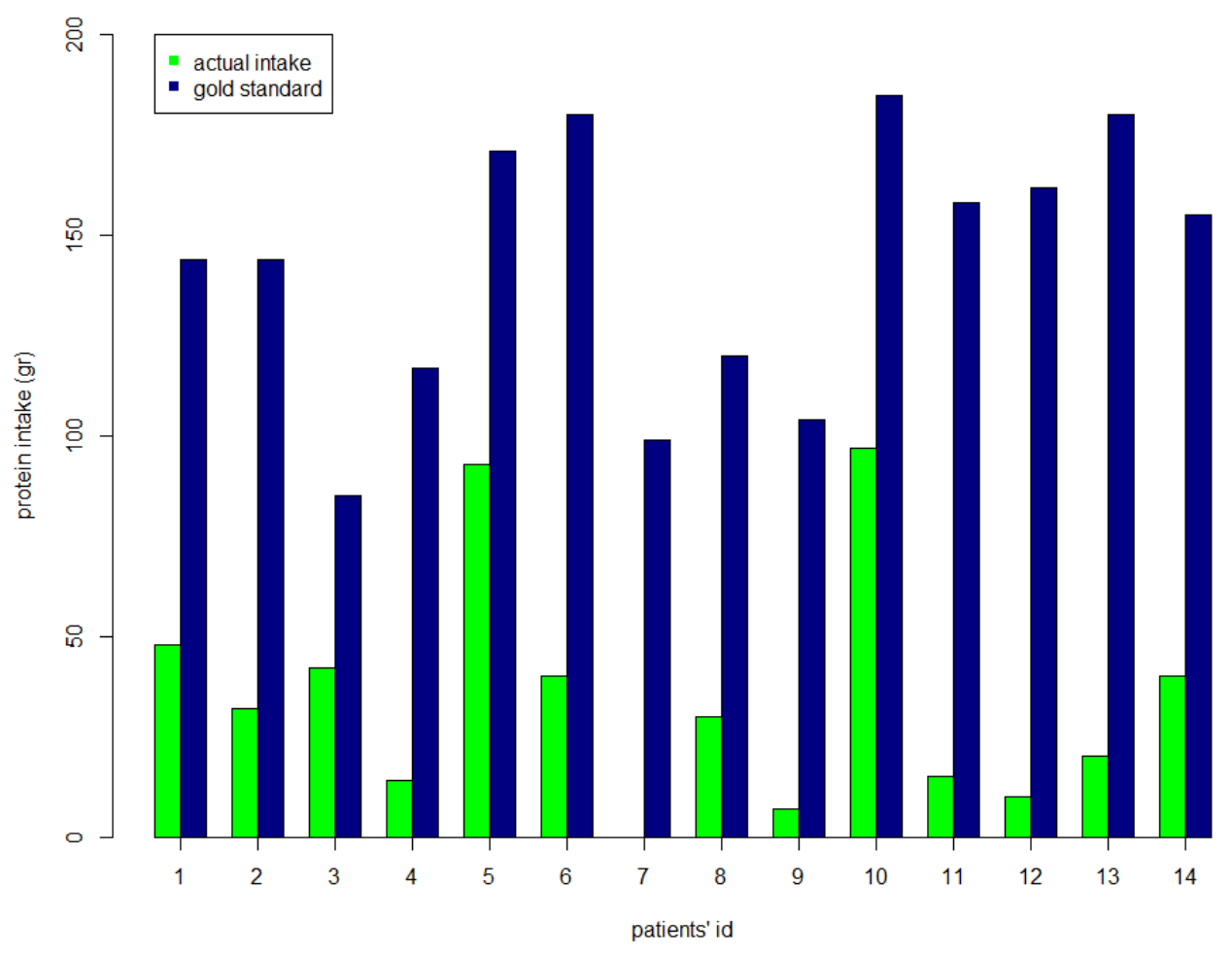




\section{Discussion}

\section{Principal Findings}

In recent years, several studies have focused on the importance of an adequate caloric intake in critically ill subjects. However, specific evidence about protein intake (adequate amount to be administered, adverse outcomes associated with inadequate protein intake) is sparse, even though several studies have demonstrated that in critically ill patients protein breakdown is greatly increased $[3,11,20]$. Adequate provision of protein represents a relevant issue in patients admitted in ICU, because pathological conditions such as surgical procedures and infection diseases result in increased protein requirements [11,21]. A high protein intake is recommended during the early phase of the ICU stay due to increased catabolism [9]. Allingstrup et al [22] observed a lower mortality in patients receiving a mean of 1.46 (SD 0.29) $\mathrm{g} / \mathrm{kg} /$ day than those receiving 0.79 (SD 0.29) or 1.06 (SD 0.29) $\mathrm{g} / \mathrm{kg} /$ day. This suggested that an optimal protein provision may result in better clinical outcomes compared to an optimal caloric provision alone in critically ill patients [21].

Considering this framework, the main issue in the nutritional management of ICU patients is represented not only by the identification of the most adequate daily caloric intake but also by the identification of the optimal contribution of each nutrient to the daily caloric intake, focusing particularly on protein content. The aim of our study protocol is to provide evidence about the effectiveness of a protein-fortified diet in patients admitted to ICU.

To assess the feasibility of this study protocol, a pilot study was conducted. Consistent with previous research [3,11], our feasibility study confirmed that critically ill patients had a severe protein catabolism that resulted in a strong negative NB. Literature has suggested that this situation may result in prolonged ventilator dependence and increased risk of brain dysfunction, neuromuscular weakness, metabolic changes, muscle wasting, malnutrition, skin breakdown, and symptoms distress like pain, anxiety, and depression [23].

Although the NB was negative in all patients, we observed that cumulative NB in the first 72 hours was different among subjects observed. This is probably due to an interindividual variability in the lean body mass that results in a different amount of protein metabolism waste. Beyond its action on protein metabolism, dietary protein intake affects body composition [18]. This interindividual variability might be considered in the estimation of protein intake. However, while a high protein intake is able to preserve lean mass, especially during the early or most catabolic phases of illness, the specific goal of protein requirement to minimize the loss of lean mass is not yet clear $[21,24]$. Additionally, together with the marked negative NB, actual protein intake was found to be dramatically lower than that recommended by international guidelines for patients undergoing mechanical ventilation.

Weight-based equations (1.2-2 g/kg/day) may be used to monitor adequacy of protein provision $[2,25]$, but in adult critically ill patients admitted to ICU, it is difficult to achieve this target. This is because standard nutritional formulations are rich in lipid and carbohydrate calories, but the protein content is inadequate. Furthermore, our findings showed that the contribution of EN to caloric intake remained stable over the period of observation. This may be attributable to feeding intolerance and high gastric residual volumes or to interruptions for medical procedures (eg, bronchoscopy, computed tomography, as with patient 7). If $\mathrm{EN}$ is insufficient, supplemental PN should be considered [9]. However, even if $\mathrm{PN}$ administration progressively increased during the period of observation, the composition of both PN or EN did not allow the achievement of protein optimal requirements.

\section{Conclusions}

Even though several studies have shown that the provision of an appropriate protein intake may reduce net muscle catabolism, to our knowledge this is the first study protocol aimed at comparing clinical outcomes of standard and protein-fortified diet in an ICU population. Results of the feasibility study clearly confirmed that protein provision in ICU patients is below that recommended in international guidelines and that this results in impaired NB. Moreover, it provided evidence that protein catabolism is different among patients, probably due to differences in body composition (eg, lean body mass). Such interindividual variability will be further analyzed in the trial to understand if and how it may be considered in the titration of protein intake.

\section{Conflicts of Interest}

None declared.

\section{Multimedia Appendix 1}

Energy and protein intake calculation for intervention group only.

[PDF File (Adobe PDF File), 17KB-Multimedia Appendix 1]

\section{Multimedia Appendix 2}

Peer review and approval from Etichs Committee.

[PDF File (Adobe PDF File), 1MB-Multimedia Appendix 2]

\section{References}


1. McClave SA, Martindale RG, Vanek VW, McCarthy M, Roberts P, Taylor B, ASPEN Board of Directors, American College of Critical Care Medicine, Society of Critical Care Medicine. Guidelines for the provision and assessment of nutrition support therapy in the adult critically ill patient: Society of Critical Care Medicine (SCCM) and American Society for Parenteral and Enteral Nutrition (ASPEN). JPEN J Parenter Enteral Nutr 2009;33(3):277-316. [doi:

10.1177/0148607109335234] [Medline: 19398613]

2. McClave SA, Taylor BE, Martindale RG, Warren MM, Johnson DR, Braunschweig C, Society of Critical Care Medicine, American Society for Parenteral and Enteral Nutrition. Guidelines for the provision and assessment of nutrition support therapy in the adult critically ill patient: Society of Critical Care Medicine (SCCM) and American Society for Parenteral and Enteral Nutrition (ASPEN). JPEN J Parenter Enteral Nutr 2016 Feb;40(2):159-211. [doi: 10.1177/0148607115621863] [Medline: 26773077]

3. Anders S, Albert R, Miller A, Weinger MB, Doig AK, Behrens M, et al. Evaluation of an integrated graphical display to promote acute change detection in ICU patients. Int J Med Inform 2012 Dec;81(12):842-851 [FREE Full text] [doi: 10.1016/j.ijmedinf.2012.04.004] [Medline: 22534099]

4. Singer P, Anbar R, Cohen J, Shapiro H, Shalita-Chesner M, Lev S, et al. The tight calorie control study (TICACOS): a prospective, randomized, controlled pilot study of nutritional support in critically ill patients. Intensive Care Med 2011 Apr;37(4):601-609. [doi: 10.1007/s00134-011-2146-z] [Medline: 21340655]

5. Picolo MF, Lago AF, Menegueti MG, Nicolini EA, Basile-Filho A, Nunes AA, et al. Harris-Benedict equation and resting energy expenditure estimates in critically ill ventilator patients. Am J Crit Care 2016 Jan;25(1):e21-e29 [FREE Full text] [doi: 10.4037/ajcc2016758] [Medline: 26724304]

6. Faisy C, Guerot E, Diehl J, Labrousse J, Fagon J. Assessment of resting energy expenditure in mechanically ventilated patients. Am J Clin Nutr 2003 Aug;78(2):241-249 [FREE Full text] [Medline: 12885704]

7. Hoffer L, Bistrian B. What is the best nutritional support for critically ill patients? Hepatobiliary Surg Nutr $2014 ; 3(4): 172$. [doi: 10.3978/j.issn.2304-3881.2014.08.03]

8. Oshima T, Heidegger C, Pichard C. Protein in nutritional support: the newborn hero for the critically ill? Crit Care 2014 Nov 17;18(6):592 [FREE Full text] [doi: 10.1186/s13054-014-0592-z] [Medline: 25672435]

9. Singer P, Hiesmayr M, Biolo G, Felbinger T, Berger M, Goeters C. Pragmatic approach to nutrition in the ICU: Expert opinion regarding which calorie protein target. Clinical Nutrition 2014;33(2):246-251. [Medline: 24434033]

10. Faisy C, Lerolle N, Dachraoui F, Savard J, Abboud I, Tadie JM. Impact of energy deficit calculated by a predictive method on outcome in medical patients requiring prolonged acute mechanical ventilation. Br J Nutr 2009;101(07):1079-1087. [doi: 10.1017/S0007114508055669] [Medline: 18778528 ]

11. Weijs P, Looijaard W, Beishuizen A, Girbes A, Oudemans-van Straaten H. Early high protein intake is associated with low mortality and energy overfeeding with high mortality in non-septic mechanically ventilated critically ill patients. Critical Care 2014;18(6):1. [doi: 10.1186/s13054-014-0701-z] [Medline: 25499096]

12. Bellorin-Font E, Ambrosoni P, Carlini RG, Carvalho AB, Correa-Rotter R, Cueto-Manzano A, Comité de Metabolismo Mineral y Óseo, Sociedad Latinoamericana de Nefrología e Hipertensión (SLANH). Clinical practice guidelines for the prevention, diagnosis, evaluation and treatment of mineral and bone disorders in chronic kidney disease (CKD-MBD) in adults. Nefrologia 2013;33 Suppl 1:1-28 [FREE Full text] [doi: 10.3265/Nefrologia.pre2013.Feb.11945] [Medline: 23629678]

13. Frankenfield D, Ashcraft C. Estimating energy needs in nutrition support patients. JPEN J Parenter Enteral Nutr 2011 Sep;35(5):563-570. [doi: 10.1177/0148607111415859] [Medline: 21832143]

14. Oshima T, Heidegger C, Pichard C. Supplemental parenteral nutrition is the key to prevent energy deficits in critically ill patients. Nutr Clin Pract 2016 Aug;31(4):432-437. [doi: 10.1177/0884533616651754] [Medline: 27256992]

15. Knaus W, Draper E, Wagner D, Zimmerman J. APACHE II: a severity of disease classification system. Crit Care Med 1985 Oct;13(10):818-829. [Medline: 3928249]

16. Le Gall JR, Neumann A, Hemery F, Bleriot J, Fulgencio J, Garrigues B, et al. Mortality prediction using SAPS II: an update for French intensive care units. Crit Care 2005;9(6):R645-R652 [FREE Full text] [doi: 10.1186/cc3821] [Medline: 16280063]

17. Dickerson R, Tidwell A, Minard G, Croce M, Brown R. Predicting total urinary nitrogen excretion from urinary urea nitrogen excretion in multiple-trauma patients receiving specialized nutritional support. Nutrition 2005 Mar;21(3):332-338. [doi: 10.1016/j.nut.2004.07.005] [Medline: 15797675]

18. Moizé V, Pi-Sunyer X, Vidal J, Miner P, Boirie Y, Laferrère B. Effect on nitrogen balance thermogenesis, body composition, satiety, and circulating branched chain amino acid levels up to one year after surgery: protocol of a randomized controlled trial on dietary protein during surgical weight loss. JMIR Res Protoc 2016;5(4). [doi: 10.2196/resprot.6438]

19. R: A Language and Environment for Statistical Computing. Vienna: R Foundation for Statistical Computing; 2015.

20. Hoffer L, Bistrian B. Appropriate protein provision in critical illness: a systematic and narrative review. Am J Clin Nutr 2012 Sep;96(3):591-600 [FREE Full text] [doi: 10.3945/ajcn.111.032078] [Medline: 22811443]

21. Cunha H, Rocha E, Hissa M. Protein requirements, morbidity and mortality in critically ill patients: fundamentals and applications. Rev Bras Ter Intensiva 2013 Mar;25(1):49-55 [FREE Full text] [Medline: 23887760]

22. Allingstrup MJ, Esmailzadeh N, Wilkens KA, Espersen K, Hartvig JT, Wiis J, et al. Provision of protein and energy in relation to measured requirements in intensive care patients. Clin Nutr 2012 Aug;31(4):462-468. [doi:

10.1016/j.clnu.2011.12.006] [Medline: 22209678] 
23. Nelson JE, Cox CE, Hope AA, Carson SS. Chronic critical illness. Am J Respir Crit Care Med 2010 Aug 15; 182(4):446-454 [FREE Full text] [doi: 10.1164/rccm.201002-0210CI] [Medline: 20448093]

24. Plank LD. Protein for the critically ill patient—what and when? Eur J Clin Nutr 2013 May;67(5):565-568. [doi: 10.1038/ejcn.2013.34] [Medline: 23403870]

25. Dickerson RN, Pitts SL, Maish GO, Schroeppel TJ, Magnotti LJ, Croce MA, et al. A reappraisal of nitrogen requirements for patients with critical illness and trauma. J Trauma Acute Care Surg 2012 Sep;73(3):549-557. [doi:

10.1097/TA.0b013e318256de1b] [Medline: 23007014]

\title{
Abbreviations
}

APACHE: Acute Physiology and Chronic Health Evaluation

BMI: body mass index

BUN: blood urea nitrogen

EN: enteral nutrition

HBE: Harris-Benedict equation

IC: indirect calorimetry

ICU: intensive care unit

ITT: intention-to-treat

KDIGO: Kidney Disease Improving Global Outcomes

NB: nitrogen balance

PN: parenteral nutrition

RCT: randomized controlled trial

REDCap: Research Electronic Data Capture

REE: resting energy expenditure

SAPS: Simplified Acute Physiology Score

UUN: urine urea nitrogen

\author{
Edited by G Eysenbach; submitted 04.12.16; peer-reviewed by P Berchialla, F Garzotto, UR Mikkelsen; comments to author 29.12.16; \\ revised version received 21.01.17; accepted 27.02.17; published 09.05.17 \\ Please cite as: \\ Danielis M, Lorenzoni G, Cavaliere L, Ruffolo M, Peressoni L, De Monte A, Muzzi R, Beltrame F, Gregori D \\ Optimizing Protein Intake and Nitrogen Balance (OPINiB) in Adult Critically Ill Patients: A Study Protocol for a Randomized \\ Controlled Trial \\ JMIR Res Protoc 2017;6(5):e78 \\ URL: http://www.researchprotocols.org/2017/5/e78/ \\ doi: $10.2196 /$ resprot.7100 \\ PMID: 28487264
}

CMatteo Danielis, Giulia Lorenzoni, Laura Cavaliere, Mariangela Ruffolo, Luca Peressoni, Amato De Monte, Rodolfo Muzzi, Fabio Beltrame, Dario Gregori. Originally published in JMIR Research Protocols (http://www.researchprotocols.org), 09.05.2017. This is an open-access article distributed under the terms of the Creative Commons Attribution License (http://creativecommons.org/licenses/by/2.0/), which permits unrestricted use, distribution, and reproduction in any medium, provided the original work, first published in JMIR Research Protocols, is properly cited. The complete bibliographic information, a link to the original publication on http://www.researchprotocols.org, as well as this copyright and license information must be included. 